\title{
Buddhism and Confucianism in the Tangut State
}

\author{
KIRILL SOLONIN
}

\begin{abstract}
From a generic perspective, the Tangut ideological system can be represented as the conflation of three major factors: in the course of their history, the Tanguts were open to ideological inflows originating mainly on the Central Plains (1, Buddhism and Confucianism) and the Tibetan Plateau (2, Buddhism). These two inflows encountered the Tangut indigenous ideology (3), which had obviously emerged before the proclamation of the Tangut State, and is scarcely known. These elements developed into a unique amalgamation provisionally identified as 'Tangut ideology,' or the 'Tangut tradition.' This 'tradition' cannot be reconstructed in its entirety: our sources are limited to the surviving textual materials in the Tangut language and scattered evidence in a variety of Chinese sources, and, to an even lesser extent, in the Tibetan chronicles. This paper seeks to deal with just one aspect of the multifaceted Tangut ideological system: the relation between Buddhism and Confucianism in the Tangut State. The main conclusion is that despite the fact that the role of Confucianism is not clearly evident in existing sources, the ultimate importance of Confucian influence is the formation of the Tangut wen 文.
\end{abstract}

KEYWORDS Tangut writing system, Buddhism, Chinese learning, Tangut state, Confucianism, Tangut rituals

\section{Introduction}

It has become somewhat commonplace to identify the Tangut ideology in terms of Buddhism versus Confucianism, or as a combination thereof: the issue of the balance between Confucianism and Buddhism in the Tangut civilization determined much of the subject matter of the discourse on the history of the Tangut kingdom. In my opinion, in the Tangut case, the opposition between Buddhism and Confucianism is merely a scholarly construct and not necessarily representative of the historical reality of the Tangut Empire (ca. 1038-1227, in Chinese sources known as Xixia 西夏). The process of creating the Tangut culture and ideology can be viewed diachronically: one is confident that the balance of its constituents, which can be provisionally identified as Confucianism, Buddhism, and Tangut national mythology, fluctuated in each given period, but in which manner we are not exactly sure; the diachronic vector can only be reconstructed from the currently available texts, which form a synchronic snapshot of the Tangut civilization at its height in the mid-twelfth century. 
Such a projection is not much different from linguistic reconstruction; however, the results which it yields are not as reliable. One reason for our fragmentary understanding of the formation of the Tangut national ideology is that general ideas about the history of Central China and Tibet are sometimes mechanically projected on the Tangut materials. Therefore, scholarship (including the present author) quite often misinterprets textual and historical evidence so as to adjust it to pre-mediated theories. Below I would like to deal with one such problem: the relationship between Buddhism and Confucianism in the Tangut State.

The Tanguts, ${ }^{1}$ known by the Chinese as the Dangxiang (党項), as mentioned in the seventhcentury Sui shu 隨書 (Book of the Sui Dynasty), were a Tibeto-Burman people originally from the Ordos region. In the late tenth century, they established a state which they themselves called the Great State of White and High (Chin. Da baigao guo 大白高國) or the Great Xia (Chin. Daxia 大夏), in both Tangut and Chinese, in the area of the Great Loop of the Yellow River (Chin. Huang he 黄河) until it was destroyed by the Mongol offensive in 1227. Neither 'Tangut' nor Dangxiang were actual self-appellations of the Tangut people, who preferred to call themselves 纳, the general term phonetically rendered through Chinese mi (彌), and translated by the Tangut themselves as fan (番).

The Tangut population of the Tangut Empire consisted of a variety of groups. Two major divisions of the Tangut people were 须, which implied the Tangut people in general, and 夏棈 (transcribed into Chinese as le 勒). ${ }^{2}$ Following the famous Ode to the Sacred Ancestors of the

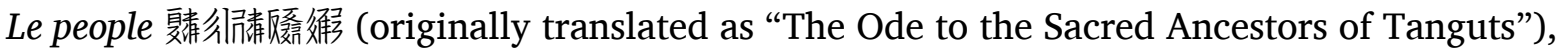
one can infer that the Le people formed the elite of the Empire. The relationship between the inexplicit division into $L e$ and $M i$ and better-known groups such as the Black Heads (Tang. 彻 桶) and Red Faces (Tang. 㷇效) is not straightforward and has to be investigated further. In any case, these numerous groups formed the ethnic entity known as the Long Minyag (Tang. 级多麦乘). ${ }^{3}$ The multifaceted structure of Tangut society definitely influenced the formation of Tangut culture and ideology, but to which degree remains to be clarified.

In the Chinese historical sources, the Tangut state emerges under the title of the Western Xia or Xixia (西夏)—designed to discriminate the Tangut empire from the Great Xia State (大 夏), founded by the leader of the Mongolic-speaking xiongnu (匈奴) tribes Helian Bobo (381425, 赫連勃勃) in the same area in 407. In scholarly literature, the term Xixia-though not entirely accurate-is the most widely applied one, and therefore this paper uses it. The term Xixia remained irrelevant to the Tanguts while the Great State of White and High (Tang. 解

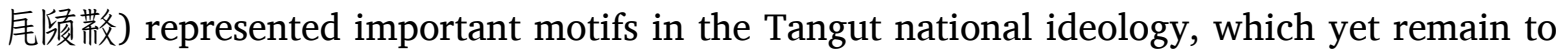
be clarified. One observation here is obvious: the name of the Tangut State emerged from the Tangut indigenous mythology and was representative of neither Buddhism nor Confucianism. ${ }^{4}$ This is but one of the most well-known examples indicative of the fact that the

$1 \quad$ Below, I only provide the Tangut characters with the Chinese equivalents. Providing transcription would have been difficult technically and will not add much to the discussion. For the Tangut texts mentioned in the paper, I provide English translations of the titles and version in the original script. In case the Chinese original of a certain work is solidly established, I do not use Tangut.

$2 \quad$ Suggested by Nie Hongyin 聶鴻音.

3 To the best of my knowledge, no English translation of the "Ode" exists. The above rendering is based on my own English translation of the "Ode," which is in many ways dependent on previous research (see Kychanov 1968).

4 Peng Xiangqian (2012) argued that the name of the state implies associations of 'white' and 'West' and an element of "metal" in the wuxing system; Nevskij (1960), in his debate with Wang Jingru, based his argumentation on historical and geographical considerations, proceeding from the understanding that the original homeland of the Tangut people was most probably the area of Eastern Tibet and the adjacent regions, roughly corresponding to the modern provinces Sichuan and Gansu of the People's Republic of 
Tangut ideology cannot be labelled as either Confucian or Buddhist, or as anything else, for that matter, but requires a more meticulous analysis proceeding from an in-depth reading of the native sources.

This being said, one should admit that the Tangut textual heritage reveals a variety of external impacts on the Tangut culture. Although no calculations have been done yet, one can clearly observe that the translated literature far exceeds the number of compositions currently identified as the works of Tangut native literature. Despite this established fact, Tangut culture was not formed based on borrowings: there are various non-indigenous elements of the complex system of Tangut culture and ideology which can be traced back to their respective source traditions with varying degree of certainty, but it was the combination of these otherwise obvious impacts with the Tangut indigenous sources of self-identification and representation which created the unique Tangut tradition evident in the extant Tangut textual heritage. If one believes that the surviving Tangut textual heritage represents the ideological outlook of the Tangut state, then terms like Buddhism and especially Confucianism are heuristic devices that allow arranging groups of texts of varying provenance and subject matter together. Thus, these labels are useful in grouping the texts but are probably not representative of a once existing historical reality.

The approach taken here is that Tangut intellectual history may be productively examined not from the perspective of the Buddhist and Confucian dichotomy, but from the point of view of the combination of the so-called 'Han rites' and the 'Tangut rituals' (Tang. 䊀瑷後 雔, Chin. hanyi fanli 漢儀番禮). These two terms, which equally emerge in both Tangut and Chinese sources, label two main currents of the ideological and cultural controversy throughout Tangut history. The meaning of these terms is necessarily broad and somewhat vague, but reflexive of the alternative of following either the Tangut way or adapting the Chinese patterns. As becomes apparent in the texts, the basic foundation of 'Tangut rituals' was the Tangut writing system.

One piece of evidence for this is the famous proclamation by the first Tangut Emperor Jingzong (景宗, Yuanhao 元昊, 1003-1048):

In my impudence, I have created [the] small Tangut script, and changed the clothing and hats of the Great Han. Since clothing and hats were created, and the script was promoted, rituals and music started to spread, and ritual utensils were already complete. Therefore, the Tibetans, Tartars, Zhangye and Jiaohe [Uighurs], all subjugated [to me]. ${ }^{5}$

This paragraph is indicative in the sense of the conscious deviation by Tangut rulers from the patterns of the Great Han. Interestingly, although the Tangut version of this proclamation is unknown, one can infer that the Tangut character used here is 䊉, which can be translated as han (漢)—not in the political but in the cultural context. In his proclamation, Yuanhao presented the essence of Tangut rituals, which was generally to serve as the alternative for 'Han rites.' That is, in the compound 'Han rites' and 'Tangut rituals,' the emphasis is not on 'rituals' but on the opposition between han and fan.

In my understanding, Han rites and Tangut rituals were the two basic concepts around

China. The dangxiang tribes were resettled in the area of the Great Loop of Huanghe during the second half of the eighth century, as an aftermath of the long period of Sino-Tibetan wars. Current scholarship suggested a variety of interpretations, all of which are arbitrary.

5 臣偶以狂斐, 制小蕃文字, 改大漢衣冠。衣冠既就, 文字既行, 禮樂既張, 器用既備, 吐蕃、塔塔、張掖、交河, 莫不從伏 (Song Shi 宋史1985, 4258). 
which the Tangut ideological agenda gravitated throughout the recorded history of the Tangut Empire. In what follows, I will try to examine how these concepts were represented in Tangut literature, and the role of Confucianism and Buddhism therein.

\section{State of the Field}

Traditionally, scholarship identifies two major outside impacts on the formation of the Tangut tradition: Sinitic and Tibetan. This observation is generally based on a scanning analysis of the available Tangut textual heritage. This scanning reveals that the Tibetan influence was limited to the religious dimension, whereas the Sinitic impact was multilateral: it included the aspects identified by scholars as 'secular ideology' as opposed to 'religious beliefs,' proceeding from the nature of texts, which had been identified by early scholarship as secular and religious. The former was mechanically equated with Confucianism, the latter with Buddhism, and each was exemplified by a specific set of texts. Thus, the first attempts to systematize the Tangut textual corpus intended to discriminate between secular (i.e. Chinese classical literature and military, medical treatises, lexicography) and religious (i.e. Buddhist) texts. In the first approximation, this schema provides a convenient tool for the classification of the received Tangut tradition. However, the veracity and adequacy of such a representation is questionable: while Buddhist texts are easily identifiable in terms of their subject matter, the secular corpus was identified on the principle that everything which is not Buddhist is Confucian. This initial division proceeded from the needs of linguistic analysis: so-called 'secular' texts were believed to offer better research perspectives because their Chinese originals were easily identifiable.

From the perspective of the historical research, scholars generally agree that Buddhism was a major factor of political legitimation in the Tangut Empire. In Western scholarship, this hypothesis was elaborated by Ruth Dunnell. ${ }^{6}$ In 1996, Li Fanwen (李範文) published a short paper entitled "The Influence of Tibetan Buddhism on Xixia," (1996) in which he argued that Tibetan Buddhism was the 'state religion' (Chin. guojiao 國教) in the Tangut Empire, and the influence of Tibetan Buddhism determined the outlook of Tangut Buddhism in general.

$6 \quad$ The first and by far the most influential western publication on the subject is The Great State of White and High (Dunnell 1995), in which Dunnell makes the role of Buddhism in the Tangut state formation the main subject of her study. The approach taken in this monograph is such that Buddhism was a major instrument of political legitimation in the Tangut Empire, especially during the so called 'regencies', i.e. the period from the death of the first monarch Yuanhao (1038-1048, 元昊) until the late eleventh century, when young Emperor Qianshun (1086-1139, 乾順) finally emancipated himself and the imperial clan from the domination of the empress-dowager's Liang clan. In a nutshell, the history of political confrontation in the Tangut State is simple: Yuanhao established both Buddhist and Confucian traditions, and at the same time attempted to preserve Tangut national identity (i.e. the 'Fan rituals' [Tangut rituals] 蕃/番禮). During the regencies, when the power belonged to the empress dowager's clans (Mozang 沒藏, Liang 梁), Buddhism acquired a crucial role in the legitimation of power. This process was probably accompanied by the promotion of national rituals; that is, Tangut rituals were advocated by the 'conservatives' (the Tangut tribal aristocracy headed by the clans of empresses), while the 'modernists' (the imperial clan Ngwemi) supported Han rites. Emperor Qianshun exterminated the Liang clan, restored Confucian education, appointed professors to both Chinese and Tangut Schools in Xixia, and Confucianism continued to thrive in the Tangut Empire until the collapse of the state. Emperor Renzong (1124-1193, 仁宗) elevated Confucius to the status of Emperor, established the examination system, and personally participated in the sacrifices for Confucius. These measures were combined with continuous support for Buddhism; this ideological duality determined the complexity of the Tangut state ideology, which also incorporated elements of Tangut indigenous beliefs. As Dunnell argues, the Tangut model of Buddhist legitimation proved so powerful that its remainders are discovered throughout the history of the former Tangut realm even after the demise of the Tangut Empire in 1227. 
The idea that the Tangut monarchs were 'semi-spiritual rulers' goes back to Nikolai Aleksandrovich Nevskij, who suggested this in his seminal paper "The Cult of Celestial Bodies in the Tangut State" (1960, vols. 1: 312-25). In reply to Li's article from 1996, Shi Jinbo (史金波) published his "Several Issues Concerning Buddhism and Confucianism in Xixia" (2010). In this article, Shi tried to juxtapose the relative positions of Tangut Buddhism and Confucianism and concluded that Buddhism remained the basic ideological and religious foundation of the Tangut Empire, but could not have been proclaimed the official religion due to the overall tolerance (both ethnic and religious) of the Tangut authorities.

Later, Evgenij Ivanovich Kychanov (2000) summarized the information on the legal status of the Buddhist communities in the Tangut Empire and suggested that although Buddhism was a powerful religion among the multiethnic population of the Tangut Empire, the state itself was mostly Confucian. This observation draws upon the Sinitic rudiments, which are easily identifiable in the monuments of Tangut law; in the texts studied by Kychanov, he discovered no traces of Buddhism. ${ }^{7}$ The aforementioned Sinitic elements were again equated with Confucianism. Such an equation was purely heuristic, or, in some cases, proceeded from a failure to discriminate between the Confucian teaching and the texts associated with "the art of government", imported from the ruling Chinese dynasties.

This means that early scholarship came to a correct conclusion proceeding from an incorrect assumption: it was not aware of the opposition between 'secular' (Tang. 钢, Chin. su 俗) and 'sacred' (Tang. 㣙, Chin. sheng 聖) texts, preserved in the Tangut texts. The contents of these two categories in existing Tangut literature remains to be clarified: the 'sacred' definitely included the Buddhist texts, but probably also such compositions as The Sea of Meanings Established by

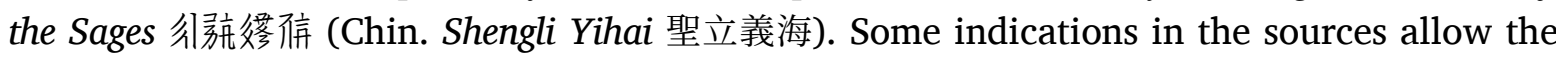
suggestion that the Confucian classics were included into the 'secular' category.

Major manifestations of the Confucian influence can be found in the Tangut administration and legal system: this is historically justifiable, since the Tangut law was dependent, in many ways, on the law codes of the Tang (618-907, 唐) and Song (960-1279, 宋) Dynasties. The rest of the ideological sphere was the Buddhist domain. This approach, limiting Confucian influence to the realm of the "art of government" (Chin. rushu 儒術), was developed by Li Huarui, and is more productive than the previous ones. ${ }^{8}$ This would automatically include the Tangut legal literature into the 'secular' corpus. The introductory verse to The Sea of Meanings Established by the Saints differentiates between the Law of the Buddha, the Law of Salvation (Tang. 㣴禒, Chin. jiufa 救法, i.e. the Tangut term for Daoism), and 'secular teaching'

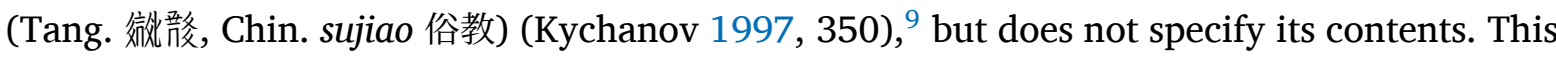
means that the boundary between sacred and religious in Tangut literature was recognized

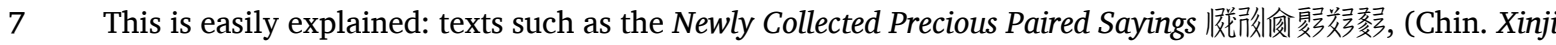
jinhe $c i$ 新集锦合辭) are not ideological compositions, in which one would expect to find traces of Buddhism. Confucianism is not discernable in this text either.

8 As Li Huarui (李華瑞) indicated, the usage of the term 'Tangut Confucianism' can be misleading, creating the impression that a scholarly tradition similar to the Chinese notion of Confucianism (Chin. ruxue 儒學) once existed in the Tangut Empire. A more adequate approach is to limit the notions of Confucianism in Xixia to a vague concept of 'political culture influenced by Confucianism' and an educational system based on the Confucian texts. This approach, developed mostly by Li Huarui, is more productive as an explanatory model than a straightforward definition of the Tangut Empire as either Confucian or Buddhist. A major obstacle to adopting this point of view entirely would be the presence of a visible system of a Buddhist state cult in the Tangut Empire: that is, while defining the ideological makeup of the Tangut State in general, one should discriminate not only between Buddhist and Confucian elements, but between 'official' and 'popular' elements within Tangut Buddhism itself (see Li Huarui 2010). I am referring to the reproduction of the text, translations mine. 
but not clearly delineated. As follows from the introductory verses to The Sea of Meanings Established by the Saints, as well as from other sources, what was important for the Tanguts was the fact that all works of literature were composed using the national script. That is, to the extent that the Tangut ideology is represented by Tangut literature, one can observe that the Buddhism/Confucianism paradigm, or even the 'religious'/'sacred' dichotomy, do not exhaust the Tangut ideological complex.

In the last years, scholars have attempted to look at the relation between Buddhism and Confucianism from the perspective of a 'fusion' (Chin. ronghe 融合) or convergence; that is, they tried to apply the paradigm of the 'three teachings of Tang-Song periods' (e.g. Yuan 2010), or explain Tangut Confucianism as historically and geographically determined. ${ }^{10}$ Both approaches offer some research perspective, but are also partially misleading since they either project the Song situation onto the Tangut materials, or proceed from unproven assumptions.

So far, authentic Tangut texts do not mention any convergence of teachings; in cases where this idea emerges, it is found only in translations from Chinese. To which degree this idea appealed to the Tanguts remains unknown. ${ }^{11}$ As far as the geographical factor is concerned, the scholarship has failed to validate the hypothesis that Tangut Buddhism, as we know it, can be derived in any form from the Buddhism of the Helan Mountains (Chin. Helan shan 賀蘭 山) area, which later became the center of Tangut Buddhism as it is recorded in such Chinese sources as the Lidai Fabao ji 歷代法寶記 (Notes on the Dharma Treasure Through Generations). This means that there is no direct transition between the varieties of Buddhism which existed in the future Tangut lands prior to their resettlement there in the mid-eighth century. The same should be true for Confucianism.

An identification of Tanguts as a nation of devoted Buddhists is probably closer to reality but remains an oversimplification: the Tangut creation myth is based on a mysterious concept of the so-called 'original West' (Tang. 䄇桁), but reveals neither Buddhist nor Confucian overtones. Furthermore, one can observe that the identification of Tangut texts as 'secular' (i.e. non-Buddhist) in many cases neglects the Buddhist vocabulary which permeates these texts. That is, once again one is not able to delineate the boundary between the doctrines, besides the mere fact that Buddhism seems to have been more productive in producing language appropriate for the doctrinal and ideological discourse.

The view advocated here is that attempts to develop an opposition between Buddhism and Confucianism in Xixia are artificial and relevant only in terms of an opposition between the Han rituals (Chin. hanyi 漢儀) and Tangut rituals (Chin. fanli 番禮) as recorded in both Chinese and Tangut sources. That is, Confucianism emerges not as a teaching or scholarly tradition, but as a tool of government, probably secondary in its importance to Buddhism, as several sources allow us to suggest. That is, one should discriminate between Confucianism

10 Scholars normally operate with general categories of Buddhism and Confucianism: for instance, since Tangut legislation is based on the Chinese legislation of the Tang and Song dynasties, which in turns draws on the paradigm of san gang wu chang 三綱五常 [three basics and five permanences], it is Confucian. Another point of view is that the dangxiang tribes were resettled in territories with the Chinese population, which was educated in the Confucian way; thus, the Tanguts naturally became followers of Confucianism (Wen Zhiyong and Cui Hongfen 2006). However, in the Tangut Odes, as well as in the entries in The Sea of Meanings Established by the Saints and Wenhai 文海 [The Sea of Writing System], one can observe that the Tangut people preserved substantial elements of their indigenous tradition, including the creation myth and state foundation myth. Thus, representing dangxiang as tabula rasa for foreign influences is at least an overgeneralized misconstruction. As Li Huarui demonstrated, the areas of Tangut resettlement in Ordos can hardly be considered as the strongholds of Confucianism.

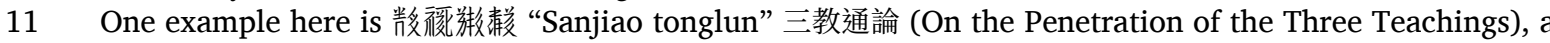
part of the so-called Suiyuan ji 隨緣集, (Notes on Various Occasion) translated from Chinese. 
as scholarly tradition and ideology of the ruling elite and administrative techniques, i.e. the 'art of government'; and in the same manner, one must discriminate between Buddhism as a belief and its scholarly tradition (texts of the Buddhist 'schools'). While Confucianism as an ideology is observed in the Tangut Empire only after the mid-twelfth century, and Confucian scholarship probably never existed in Xixia, Confucianism as the 'art of government' is traceable throughout Tangut history. The same applies to Buddhism: the important Mahāyāna scriptures had been translated during Bingchang's time (1061-1086, 秉常, the third Tangut emperor), as was established very early by Nishida Tatsuo (西田龍雄), whereas the Buddhist doctrinal compositions were translated only after the 1130s.

The present paper pursues the following point: in the Tangut Empire, Confucianism was never a powerful enough ideology to necessitate a convergence with Buddhism. The priorities in this process might have shifted during different reign periods, but the basic motivation was to create an integrated ideological system based on Tangut rituals, with which Buddhism was closely affiliated, as will become clear from the texts studied below. This purport remained fundamental for Tangut rulers throughout the history of Xixia. Again, previous scholarship seems to have neglected one important feature of the ideology process: that is all the forms of Tangut ideology, both imported and developed domestically, were rooted in one universal category, i.e. the Tangut writing system, the Tangut wen 文.

\section{Secular Literature}

To further clarify the problem of the mutual relationship between various teachings and their connection with the term wen, it might be useful to look into the structure of the corpus, which is traditionally defined as 'secular,' and considered as an important piece of evidence for Confucianism in the Tangut Empire. The ideological system of the Tanguts was multilayered, as is represented by the surviving Tangut literature corpus, available in both Tangut and Chinese. As Nie Hongyin (1999) observed, the history of Tangut literature can be divided into three periods: the first period starts in the seventh year Taiping Xingguo (太平興國, 982), i.e. when the tribal leader Li Jijian (963-1004, 李繼遷) broke away from the Northern Song (960-1126, 北宋), and generally coincides with the beginnings of independentTangut history; this period ends in 1036, when the Tangut script was invented. The end of the second period coincides with the death of the emperor Renzong (r. 1139-1193, 仁宗) in 1193. The final period of Tangut literature can be extended up to the Ming Dynasty (1368-1644, 明): the latest available Tangut text is dated to the fifth year of Xuande (宣德, 1430) reign period. Theoretically, this third period produced the most publications in Tangut, since the so-called Tangut Tripitaka, published in Hangzhou during the Yuan Yuan Dynasty (1279-1368, 元, publication date probably 1302), took place during this period. However, the most important Tangut literature works belong to the second period.

Again, dating the extant texts is not straightforward: from the colophons to the sutras, we know that important Buddhist translations belong to an earlier period than the available publications: the second period of the Tangut literature, which roughly coincides with the reigns of the emperors Liangzuo (1047-1067, 諒祚), Bingchang (r. 1067-1086, 秉常), Qianshun (1083-1139, 乾順), and Renzong (r. 1139-1193, 仁宗), encompasses both the original translations and their later revisions; thus it might not be inappropriate to specify Renzong's 
time as an independent period. ${ }^{12}$ At the same time, texts published or composed during this second period have preserved an earlier ideological stratum, belonging not even to the early stage of Tangut history but to the Tangut tribal period, preceding the resettlement in Ordos.

The available Tangut 'secular' (i.e. non-Buddhist literature) heritage can provisionally be divided into seven groups. The list below is not exhaustive, but covers most of the known monuments of the Tangut script:

1. Lexicographic compositions (including the Tangut $\cdot \mathrm{jwir}^{2}$ jjow $^{1}$ 爱徬 [The Ocean of the

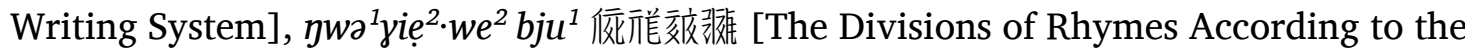

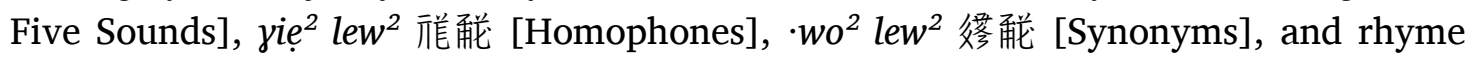
tables). These works circulated in many copies and were revised throughout Tangut history; prefaces to them are important sources not only for Tangut philology, but also for Tangut ideology and history.

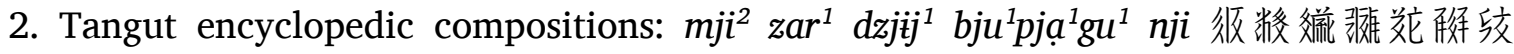
(Tangut-Chinese Timely Pearl in Hand; several copies available, generally dated around 1180-1190), The Sea of Meanings Established by the Saints 行㧧㟷不声 (mid-twelfth century). The list further includes the collection of the Tangut proverbs sjiw ${ }^{1} \operatorname{sio}^{1}$ kor $^{1}$ phjo $^{1}{ }^{1}{ }^{2} w^{1}$

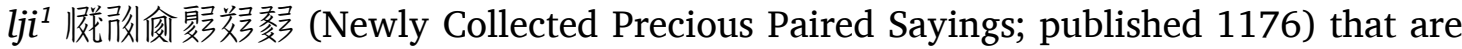
probably related to this category.

3. Still another category is the Tangut translations of the Chinese canonical literature. This category includes the Tangut translations of the Lunyu 論語 (The Analects) with commentaries, ${ }^{13}$ Mengzi and Mengzi zhangju 孟子章句 (Mengzi Primer), ${ }^{14}$ Xiaojing zhuan 孝經傳 (Commentary to the Xiaojing) originally by Lù Huiqing (1032-1111, 呂惠卿), Jingshi Zachao 經史雜抄 (Selections from Canons and History; reconstructed title) and several other works (Galambos 2015, 10:156-60). Other members of this group are the Tangut translations of the Chinese leishu 類書 (Stories Collected According to Categories), such

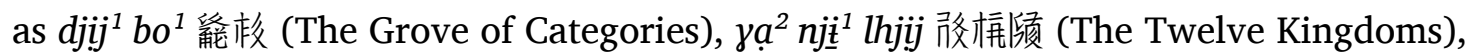

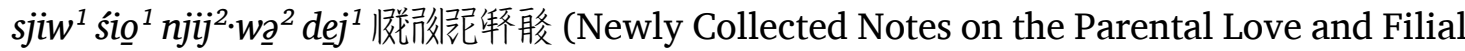
Piety), all published around 1194. Since these texts are collections of instructive stories, this category can be provisionally regarded as the Tangut version of the so-called 'books for beginners' (Chin. mengshu 蒙書), known from other archeological finds throughout Central Asia. This category also includes the text of the so-called 'Taizong's questions' (Galambos 2015, 10:135-38). The identity of this text and another manuscript from St. Petersburg, provisionally titled Taizong zeyao 太宗擇要 (The Essentials Selected for Taizong), remains to be proven (Nie Hongyin 2012, 55-59). So far, the compositions in this group are the most numerous among the 'secular' texts.

12 As Shi Jinbo argued, major Mahāyāna scriptures were translated during Bingchang's time, whereas the period of Renzong was generally a time of revisions of earlier translations. On certain occasions, we can reconstruct the editing process of the translations of both religious and secular literature. From the perspective of the Buddhist texts, one of the best examples is the study of various versions of the Tangut Lotus sūtra by Nishida Tatsuo; for the secular literature, the resources are more limited, but still allow some insights (e.g. Galambos 2015). In this last case, one cannot be exactly sure if one is dealing with the redactions or with independent translations, but the observation by Galambos that identical phrases found in various Chinese texts were translated differently is worthy of scholarly notice.

13 This Tangut composition is probably based on the Lunyu quanjie 論語全解 by Chen Xiangdao 陳祥道 (10421093).

14 According to Nie Hongyin and Peng Xiangqian 彭向前, the two texts are of different origin: Mengzi without a commentary is in fact extraction of the 'root text' from Mengzi zhu 孟子注 by Zhao Qi 趙岐 (-201); Mengzi zhangju is based on Mengzi zhuan by Chen He 陳禾 (fl. Northern Song; see Peng Xiangqian 2012). 
4. A separate category is comprised of the translations of military texts, such as Sunzi 孫子, Huang Shigong sanlue 黃石公三略 (Three Tactics of Huang Shigong), etc., which are again accompanied by commentaries; another set of compositions is medical texts. These compositions are available in several copies, which attests to their substantial circulation. ${ }^{15}$

5. Collections of Tangut poetry. The collections are not titled; the current title "Palace Odes" was coined by E.I. Kychanov and Zindaida Ivanovna Gorbacheva in their first catalog of Tangut texts, kept in St. Petersburg. These odes vary in size and can be divided into two categories: the ones composed in the language used in the bulk of the Tangut compositions, both religious and secular, and the ones composed in a different language. ${ }^{16}$ These poems include the "Great Ode" (Tang. $d z j o^{2} k h w e j^{2}$ 版姘) and “Ode to

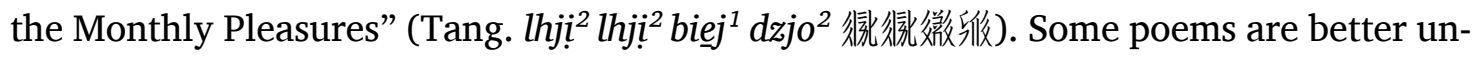
derstood than others since they were composed in the standard language; problematic places in these texts are due to the lack of familiarity with the mode of Tangut poetic expression and will eventually be resolved. These include "Ode to the Creator of the

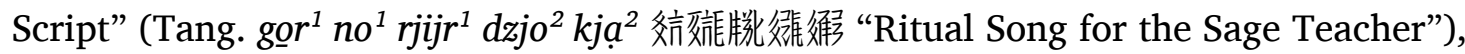

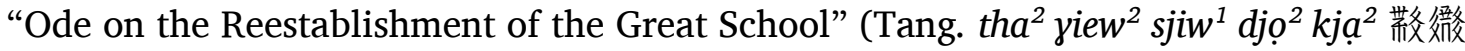

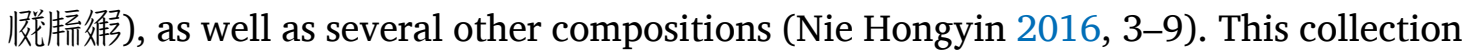
should be added up by the Shi ji 詩集 (Poetic Collection), a provisional title for a collection of poetry in Chinese discovered in Khara-Khoto. One known Tangut poet is Zhang Yuan (d. 1044, 張元), a Chinese adventurer and one-time Tangut chancellor as well as an important military commander, whose one poetic piece composed during his career in the Tangut Empire still survives. One can easily suggest that the above sets of texts are the curriculum of the Tangut and Chinese schools (Chin. Fanxue 番學, and Hanxue 漢學), which existed in the Tangut State and did not contain any creative Confucian thought.

6. A variety of epigraphy, votive inscriptions, colophons, etc., as well as official reports and communications with the Northern Song (960-1126, 北宋), the Khitan Empire (9071125, in Chinese sources known as Liao 遼), and the Jurchen Jin Dynasty (1115-1234, 金), all written in Chinese; most of these were collected by the Luo brothers in their Xixia wen cun 西夏文存 (Surviving Tangut Literature). These texts are scattered throughout the Chinese sources covering the event of the Tangut history: Xixia ji 西夏紀 (Records on Xixia), Xixia jishi benmo 西夏紀事本末 (Records of Tangut historical events from the beginning to the end), Xixia shu shi 西夏書事 (The Records of the Events of the Tangut History), Zizhi tongjian changbian 資治通鑒長編 (The Mirror Assisting the Government), Ouyang Wenzhong gong quanji 歐陽文忠公全集 (Collected Works of Ouyan Xiu), Tangut Chapters from the standard histories of the Song and Jin Dynastys and the Khitan Em-

15 E.g. colophon to the Newly Collected Notes on the Parental Love and Filial Piety reads (in Chinese translation): 中興府承旨番大學院教授臣曹道樂新集譯 “Newly collected and translated by jiaoshou of the Great Tangut School of Zhongxing fu, chengzhi, Cao Daole."

16 This distinction is based on the original study of the so called "Ode to Monthly Pleasures" by Nishida Tatsuo (Nishida Tatsuo 1986). He suggested that the connection between the well-known division of Tangut society into "red faces" and "black heads" is reflected in language. Nie Hongyin suggests the term le ni 勒 尼, which is the Chinese transcription of several terms which he believes refer to a specific group within the Tangut society. I prefer the term lhi 䫰, this is the group referred to in “Ode to the Sacred Ancestors of the Lhi" people. 
pire. ${ }^{17}$ The bulk of the texts is constituted by reports (Chin. biao 表) of the Tangut leaders to the Song court and to the courts of Liao and Jin. The reports contain territorial requests, requests for reestablishing border markets and settling territorial disputes, as well as requests for the publications of the Chinese Buddhist canon. Although at least two occasions of requests for Confucian classics are known, the texts of these requests have not survived, and are only mentioned in the historical narratives.

7. Tangut legal documents and law codes. This part of Tangut heritage consists of two bulky compositions, i.e. the Newly Promulgated Law Code of the Tiansheng Reign Period (1149-1168); another is a scattered collection of legal acts known under the provisional

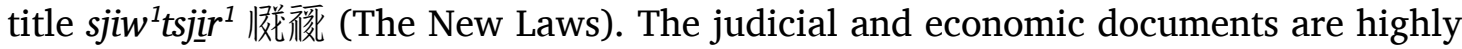
generic and offer little information regarding the study of Tangut ideology.

Another observation concerning the above classification is that the texts presented therein are of a predominantly utilitarian subject matter. Also, many of the texts presented above are lexicographical works and educational materials intended for the study of the Tangut language. The fact that these works are found in a variety of copies throughout the former Tangut territory and continue to emerge from the excavation sites indicates that language study was of primary importance for the Tanguts. This allows further speculation that the Tanguts invested specific value into their writing system and did not view it only as a medium to convey knowledge (this point will be elaborated below).

What is important about the list of texts presented above is not what is in it, but rather what is not. The traditional sources composed during the Qing Dynasty (1644-1912, 清) and widely used by scholarship, such as "The Records of the Events of the Tangut History and the Records on Xixia," contain indications that Emperor Liangzuo (1047-1067) requested the Confucian Canon from Emperor Song Renzong (1139-1193). At this moment in history, the Nine Canons (Chin. Jiujing 九經) included the Zhou yi 周易 (Classic of Changes), the Shijing 詩經 (Classic of Poetry), the Shangshu 尚書 (Classic of Documents), the Lun yu 論語 (Analects), the Chunqiu Zuo zhuan 春秋左傳 (Springs and Autumns), together with the Gongyang zhuan 公羊傳 and Guliang zhuan 谷梁 Commentaries, the Zhou li 周禮 (The Rituals of Zhou), and the Li ji 禮記 (Records of the Rituals). Mengzi, which was a popular text in the Tangut Empire, was recognized as a canonical work only after the rise of Neo-Confucianism later in the Northern Song, while the Xiao jing 孝經 (Classic of the Filial Piety) remained an extracanonical text (Li Huarui 2010). On another occasion, the Records on Xixia mention that Liangzuo again requested the Classic of Poetry, together with the "standard commentary" (zhengyi 正義). The traces of neither of these texts were discovered in the Tangut Empire; more importantly: the surviving quotations from the Shijing found in other texts demonstrate that the translators never consulted the standard commentaries to Shijing (Nie Hongyin 2003), and translated the texts on the basis of their standard knowledge of Chinese. The same is true for Lunyu and Shangshu as they emerge in the known quotations. ${ }^{18}$ In many cases, the Tangut translations do not allow the identification of the paragraphs from the classical Chinese texts; in the Buddhist translations, this happens

$17 \quad$ According to Nie Hongyin's calculation from 1999, the number of these texts totals over 50; together with the Tangut versions of the same texts, or texts of similar subject matter, the number of these texts amounts to more than one hundred (Nie Hongyin 1999).

18 One straightforward example is the inability of Tangut translators to identify the usage of 說 for 悅 in the Chinese texts. In many cases, the Tanguts would directly translate Chinese 說 with Tangut 兴 (to speak), which is an obvious mistake. In many cases, the Tangut translations do not allow the identification of the paragraphs from the classical Chinese texts. 
only rarely, and the translations are generally reliable. That is, although there is no doubt concerning the reality of the requests for Confucian books, we can suggest that the study of these texts in the Tangut Empire was never as broad or intense as one could expect, and knowledge of these texts was not common even among Tangut translators. Veneration of the Chinese classics by Liangzuo had wider implications, reflexive of his attempts to introduce 'Han rituals' as a part of his plan to emancipate the imperial clan from the Empress dowager control, but not to establish Confucianism as an alternative to Buddhist beliefs.

Another attempt to establish Confucianism occured during Qianshun's time (1083-1139), i.e. in the early twelfth century. In the eighth month of Yongan 永安 3 (1100) reign period, shortly after he emancipated himself from the domination of his mother's clan, Qianshun undertook measures to reintroduce Confucian learning in the Tangut Empire.

Specific arguments in favor of the Confucian nature of the Tangut Empire generally run as follows: The master was elevated to the status of the Emperor Propagating Culture (Chin. wenxuan di 文宣帝) during Renzong's reign in 1146, ${ }^{19}$ and Chinese schools (Chin. han taixue 漢太學, Tangut sources mention Tangut-Chinese Schools of Three Teachings, Tang. 坂粘叛多语) were re-established the following year (1147). Temples of Confucius were allegedly erected throughout the country, and Renzong is credited for his personal participation in the offerings (Chin. qin shi dian 親釋奠). Roughly during the same period, preceding the revolt of the Chu king (Chin. chu wang 楚王) Ren Dejing (mid-twelth century, 任得敬), other measures were undertaken: the Hanlin Academy was established and educational institutions for the palace youth (Chin. neixue 內學) as well as nation-wide county schools were founded. According to the Song shi 宋史 (The History of the Song Dynasty), Renzong personally taught in the palace school (Chin. qin wei xundao 親為訓導). The elevation of the inventor of the Tangut script (Chin. fanzi shi 蕃字師), Yeli Renrong (d.u., 野利仁荣), to the rank of the King-Promoter of Wisdom (Chin. Guanghui Wang, 廣惠王), and the order to compose Shilu 實錄 (Actual Records) for the Tangut court, as well the correction of the law codes, can be interpreted as signs of Confucian revival among the Tanguts. What is more important in this respect is that these measures were probably characteristic of individual inclinations of Renzong: according to the History of the Song Dynasty, before that time the schools established by Yuanhao, and then again by Qianshun, had a total enrollment of three hundred people. The real growth is observed in Renzong's time, when the schools enrolled about 3,000 students and the examination system (Chin. sheke qushi 設科取士) was introduced. The History of the Song Dynasty specifically credits Qianshun and Renzong for their sympathies towards Confucianism (Chin. $r u$ 儒).

However, it is important to mention in this respect that during Renzong's time, Confucianism did not develop as an alternative to Buddhism. Renzong was a devoted Buddhist: if one consults Kychanov's Catalog of the Tangut Buddhist Scriptures preserved in St. Petersburg, one will easily discover that most of the surviving Tangut Buddhist textual heritage dates to his period. That is, both secular and religious literature corpuses are dated to one period; the two traditions (Buddhist and non-Buddhist) represented by the two textual lineages were not alternative to each other. They were probably mutually complementary, but to which degree this was the case will become clear only when Tangut court poetry is properly studied. Another fact not to be neglected is that the reestablisment of Confucianism chronologically

19 As Li Huarui observed, this elevation of the status of Confucius in fact indicates that the Tanguts did not have a proper idea about the Confucian attitude towards the figure of the master. The elevation of Confucius was debated at various courts several times, and it was agreed that awarding Confucius the title of Emperor is, in effect, non-Confucian (Li Huarui 2010). 
coincides with resolving the Ren Dejing issue: this is probably the first moment in Tangut history when the installment of legitimate rule is expressed in Confucian terms. From the above, one can observe that the relative position of Confucianism within the overall system of Tangut literature was never dominant, and the Tangut translations of Confucian works do not reveal an attempt to reproduce any specific system of Confucian learning. In this respect, it seems more preferable to speak of Chinese, rather than Confucian, learning in the Tangut Empire. This Chinese learning was obviously present among the Tanguts as a major part of daily life but was obviously not very closely connected with Confucianism.

\section{Ideological Issues and the Tangut Script}

One of the major attributes of the newly established Tangut Empire was its script, which brought together all achievements of the Tangut people. As many Tangut sources indicate, Tanguts were especially proud of their writing system; therefore, it is useful to consider how they interpreted the role of their script from the perspective of ideology. The invention of the Tangut script was not merely of symbolic importance, but it was meant to be widely used. Below, I will consider three Tangut texts, one originally composed in Chinese and two in Tangut. Among these three texts, only one is purely Buddhist, one is a laudatory inscription, and one is a preface to a lexicographical composition. However, in my opinion all three reveal an important feature: the connection between the creation of the Tangut script and the propagation of Buddhism in the Tangut Empire. The three texts are chronologically separated by several dozen years: Zhang Shi's inscription belongs to the earliest period of the Tangut statehood, whereas the two other texts are of a much later period, probably dateable to the Renzong period.

However, the three texts demonstrate one common feature: the paramount importance of language and "written signs" in the transmission of wisdom, Buddhist or otherwise.

From the perspective of the promotion of Buddhism, the existence of the 'Great Collection of Sūtras' as early as Yuanhao's time is hypothetical: although he is said to have requested the Dazang jing 大藏經 (Chinese Tripitaka) from the Song, it is unclear whether his request was granted and what he received. The term 'reciting the Great Collections of Scriptures' (Tang.

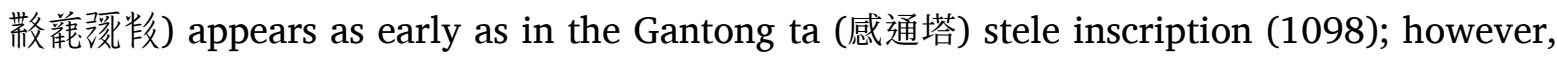
its meaning is obscure: this term probably implied not so much the real Kaibao Canon (Chin. kaibao zang 開寶藏經) but could indicate any substantial number of the Buddhist scriptures. In my understanding, the invention of the Tangut script was in many ways connected with the idea of promoting Buddhism and translating Buddhist scriptures. The hypothesis that such intentions truly existed is the existence of the famous "Da Xia guo zang sheli jieming" 大夏 國葬舍利碣銘 (Inscription Concerning the Burying of the Śarira) by Zhang Shi (d.u. 張陟), a high-ranking official of Yuanhao's time. Part of the text reads as follows:

Our Imperial Majesty endowed with literary abilities of a Sage and military prowess, [blessed] with superior humanity and supreme piety, whose wisdom and eloquence exceeds that of Tang Yao, who is as heroic as the Han [Tai] zu, [he] majestically reveres the Way of the Buddha, and had invented the Fan (Tangut script); the apple garden and lotus palace wholeheartedly adorn [the Buddhist teaching], the Golden Vehicle and Precious realm are protected with the closed palms. Now it so happened, that the famous scholars from the East and Realized 
Masters (pandita) from the West presented hundred and fifty pieces of śarira, and a joint of Buddha's finger, Buddha's arm and one uśniśa bone. Those were all put into a silver casket and golden vault, covered with iron armor and put into a stone box, covered with precious items, with Vaiśrāvana [...]. The stream was dug below it, and above it the stūpa touching the skies was erected, the fragrant flowers always scent there and metal and stone surround [the śarira]. ${ }^{20}$

The above fragment is clearly indicative of a connection between the invention of the script and the propagation of Buddhism. The ideological stance taken by Zhang Shi in this inscription is quite obvious: the comparisons between Yuanhao and the heroic rulers of antiquity, apart from being a mere figure of speech, intended to locate Yuanhao within the correct succession lineage (Chin. zhengtong 正統). His adherence to Buddhism determined the invention of the Tangut script.

The "apple garden", "the lotus palace," etc., are metaphors of the imperial court and thus indicative of the existence of an imperial Buddhist cult. From this inscription one might infer that in Zhang Shi's understanding, Yuanhao's legitimation within zhengtong was connected with both the invention of the script and his Buddhist faith. The relative value of these two factors is less certain and might reflect Zhang Shi's personal point of view as a scholar who had received traditional training. Important in this respect is that the association between Buddhism, the script, and Tangut rituals emerges in native Tangut texts, which at the same time contain no indication of the Sinitic zhengtong.

Here one can consult the famous preface to the Tangut translation of the Saddharmapundarìkasūtra (Lotus sūtra), where Yuanhao emerges under the title of the 'Wind Horn City Emperor':

'The Lotus Sūtra of the Good Law' is the secret womb of the teaching of Thus Come. The Buddha appeared in this world to present its teaching, so as to collect the two provisional vehicles and bring them together into one ultimate teaching. Its literary style is sublime and profound as the Mt. Meru, its purport is vast and deep, as is the water in the great ocean. [The sūtra] first speaks of the three realms, and collects all vehicles into one, it first uses seven parables, and gathers the five gotras into one single [Buddha] nature. This sūtra was first spoken in the Western Heaven, and then gradually was spread in the East, and was translated by Tripitaka Kumārajivia during the Hongshi (?) ${ }^{21}$ reign of the Qin Dynasty.

After this, The Wind Horn City Emperor, using the language of his realm, established the Lhwi rituals[(i.e. the Tangut)], and created the writing, and translated the sūtras. His military prowess was unparalleled and his virtue was exceptional, he ruled his people in a way which is incomparable [with any other ruler].

The previous dynasties [(i.e. previous Tangut emperors)] translated the multitude

我聖文英武崇仁至孝皇帝階下，敏辯邁唐堯，英雄 $\square$ 漢祖；欽崇佛道，撰述蕃文，奈苑蓮宫，悉心修飾, 金乘寶 界, 合掌護持。是致東土名流, 西天達士, 進舍利一百五十胃, 并中指骨一節, 獻佛手一枝, 及頂骨一方, 馨以 銀楟金棺、鐵甲石匱，衣以寶物， $\square$ 以毗沙。下通掘地之泉，上构連雲之塔，香華永楾，金石周陳。

“Da Xia guo zang sheli jieming” 大夏國葬舍利碣銘. Translation follows Lou Fuyi's copy of the text (Li Fanwen 2007, 4:877-79). The date of the stele is Xixia Tianqing 3 天慶 3, 1196, i.e. more than hundred years later than the actual events. Zhang Shi emerges in Song shi 宋史 “Xiaguo zhuan” 夏國傳 under Jingyou 3 (1036).

21 Tangut 䏕洏 probably translates Chinese Hongshi 弘始 (399-416), the reign period when the Lotus scripture was translated into Chinese by Kumārajīva. 
of sūtras; however, The Lotus sūtra [Saddharmapundarìkasūtra] was not among the translated [texts]. Today, the sacred mother and son ascended the royal throne, [they] deeply revere and believe into the Three Jewels, rule the country with virtuous deeds, so that the rituals of the ancestors are accomplished, and the future kings can study and adopt them. The actions which follow the virtue are as bright as the Sun and the Moon, the people are governed by the filial piety, and the ten thousand kingdoms all rely on us. Now, [the king] has taken a great vow: before the year cycle has changed, this one text is to be completed and distributed in the realm for everyone to hold it. Thus, the happiness of the sentient beings will be ever increasing, and the evil will be evaded for the generations to come. My literary talents are limited, and scholarship is not profound, although I do not qualify for the task, I still present a preface to the scripture. I am like a particle of dust, lost among the ten thousand [such particles] on a great mountain, [in the same manner] there is nothing I can add; just as the taste of a drop of dew coming into the ocean cannot be equated with the taste of stream coming from a gorge. ${ }^{22}$

In the present discussion, I will limit myself to only this one preface; however, there are several texts of various subject matter which all contain similar indications. From the preface, one can infer the following chronological sequence: Buddha's coming into the world; the preaching of the Saddharmapundarikasūtra; its translation into Chinese. The second set of events is: the creation of the Tangut script; the establishment of the Tangut Empire through the promotion of 'Tangut rituals' (or of the rituals of the $L e$ people); and the translation of the sūtras, which represented the ideal period of Yuanhao's rule. The preface is an ideologically motivated Buddhist text, so we do not observe connotations implying the necessity of the Tangut script to learn the Confucian Way. The third set implies the circumstances of the translation of the Saddharmapundarikasūtra: here one can observe the connection between the faith into the Three Jewels, the translation of the scriptures under imperial patronage (we do not know which imperial "mother and son" are referred to in the text), and the rule through virtuous deeds. One can further infer that the translation of the Buddhist scriptures was seen as the way to maintain and accomplish "the rituals of the ancestors", i.e. as a part of imperial duties. This observation can partially explain the existence of numerous Tangut Buddhist texts which bear the mark "imperially translated" or "imperially revised."

These observations are in accordance with the information from the Chinese standard histories that Yuanhao himself was a devoted Buddhist. Thus, the imperial patronage of the Buddhist translations was probably viewed as the way to maintain the heritage of the founding emperor. That is, the only visible ideological motivation underlying the invention of script appears to have been Buddhist. One can further suggest that at least for Yuanhao, Buddhism and national identity (expressed metaphorically as 'Tangut rituals' as opposed to 'Han rituals')

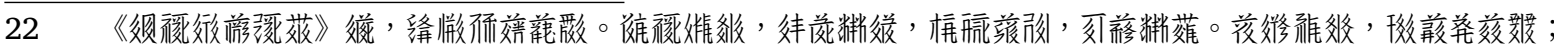

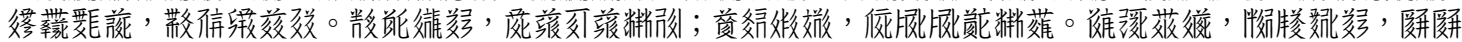

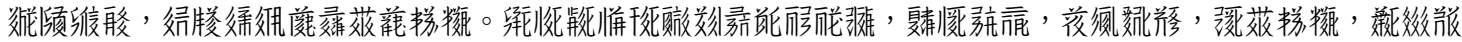

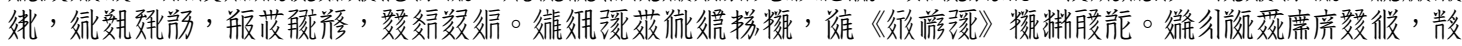

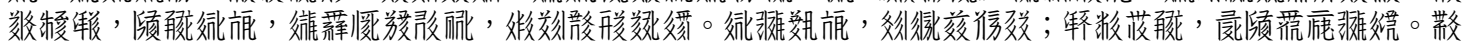

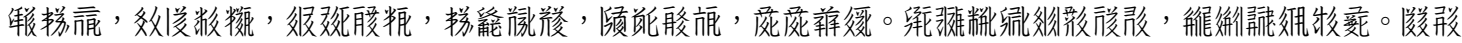

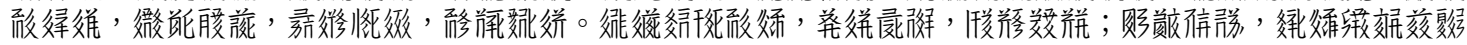

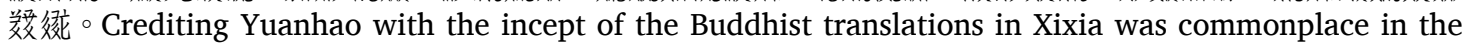
Tangut prefaces to Buddhist scriptures. The Preface to the Lotus Scripture is by far the most famous, so it is reproduced here (the transcription of the original in Shi Jinbo 1985, 10:234-35). 
formed an integral system, whereas Confucian learning did not play role in the creation of a national identity.

Important information concerning the relationship between ideology and lexicography is found in the prefaces to famous Tangut dictionaries The Rhymes of the Five Sounds and the Homophones. Although there is little doubt that the Tangut lexicography is based on the Sinitic tradition, the rationale behind the composition of the rhyme dictionaries was not to appropriate Chinese learning, but to promote the Tangut national agenda. The 'Imperial Preface' to ThebRhymes of the Five Sounds (i.e. labial, dental, alveolar, velar, glottal) presents a following picture:

If today we observe various languages, the Indians (lit. Westerners), Tibetans, and the Han people, all have the divisions of rhymes. Now, the five sounds within the writing system [(Chin. wenzi 文字) include even, rising, departing and entering [tones], therefore the initials [(Chin. zimu 字母)] are thus clarified. Pure [(unvoiced)] and muddy [(voiced)], level and oblique [(tones)] are separated; heavy [(bilabial)] and light [(labiodental)], open and close mouth [(i.e. syllables with or without medial -u-)], high and low [pitch] are explained. [Initial] letters are combined with rhymes, rhyme letters [(Chin. yunmu 韻母)] are arranged into groups [(Chin. she 攝)], this is the core of the repository of a language. [The characters] are arranged in cycles so as that can be located through each other, so that [none] is ever forgotten, and this is how they should be transmitted. I, the Emperor, through the power of my virtue, have completed these new rhymes and divisions, according to what was in the past. This is the most important in the realm, it increases the true wisdom. [The writing system as presented herein] is the source from which emerge the Collection of the Sütras of the Primordial Buddha, the rituals of the kings, the commandments and instructions, the poems of the scholars, pure and muddy, pairs of yin and yang, [calculations of] good and evil, season records, Daoism (lit. Law of Salvation), the art of healing, divination and calendars, laudations and treatises and other texts. Just as the great ocean, which is deep and wide, absorbs all the rivers and never dries up or gets overfilled, [the collection of Rhymes] contains everything what there is to look for. The Sun and the Moon shine indiscriminately, both stupid and wise can understand [this collection, in the same way they can see] the Mt. Sumeru, which is the highest of all mountains. Among all occupations, this [study of language] is unsurpassable. Among all the treasures, the treasure of language is of the highest value, that is why one should understand that this Rhymes of the Five Sounds was made in such a way as to record the initials and groups of the Precious Rhymes of the Sea of Signs, so that the names and meanings are not mixed together. ${ }^{23}$

Scholarship dates this composition to the early period of the Tangut Empire; however, according to the preface, the composition of this dictionary was a culmination of the tradition of Tangut lexicology and phonetic research, and therefore a date around the mid-twelfth

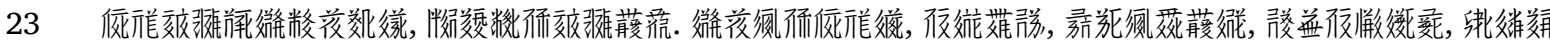

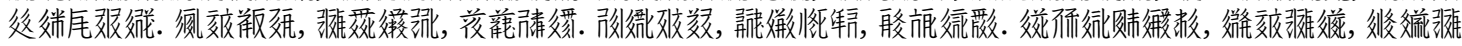

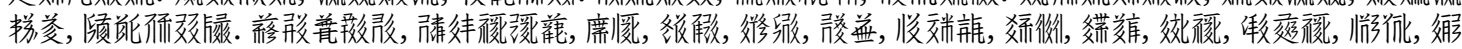

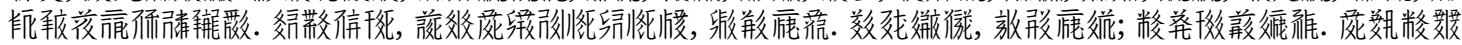

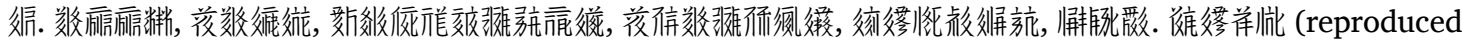
according to Ecang Heishui Cheng Wenxian 俄藏黑水城文獻1997). 
century is more adequate. As is clear from the text, the language and writing themselves were the core of the lexicographical project. The essence of this project was to secure a place for the Tanguts among 'civilized' nations, whereas the criteria for being 'civilized' were seen in the presence of dictionaries and an elaborate theory of language. That is, only the existence of the established system of language teaching allowed the promotion of wisdom, which was expressed in the signs of the writing system. This generally means that the Tanguts believed their writing system to possess independent value; they viewed is as a specific achievement instead of only a medium for transmitting knowledge. Knowledge becomes available only if is expressed through the writing system, and is thus of secondary importance.

What is of interest for the present discussion is the list of available genres of Tangut as a language. These genres seem to be presented in a hierarchical manner: the first are the Buddhist texts, followed by the rituals of the kings. The texts of this last genre are as of yet unattested in the Tangut collections. Commandments and instructions obviously represent the surviving monuments of Tangut legal literature. Of particular interest are 'the poems of scholars' (Chin. rushi 儒詩), which seemingly qualify as the Confucian classics. However, the interpretation of this term is dependent on the meaning of the Tangut term 俢, which is standardly translated as the Chinese $r u$ (儒). In the literal translation, this term returns as 'poems of the scholars', i.e. Shijing 詩經. Given the fact that the translation of the Classic of Songs is not attested in Tangut sources, one may speculate that the 'poems of scholars' in fact represent not the Chinese classics, but the specific genre of Tangut literature known as the court poetry, which is well attested in the Tangut collections. Calculations, divinations, and calendars, together with Daoism, can account for Chinese learning in the Tangut Empire, but the Confucian classics remain unattested in the list. This again shows Buddhisms' domination over Confucianism and all other forms of Chinese and native Tangut learning. Combined with the legal stipulation that the candidates for monastic posts were required to have a certain command of the phonology (Chin. yinyun 音韻), the above notes are indicative of the Buddhist rather than Confucian affiliation of Tangut lexicography.

The works belonging to the literary genres listed above are actually discovered among the monuments of Tangut literature discussed above. Previously, this paper introduced the concept of Chinese learning in the Tangut Empire: such categories as "pairs of yin and yang", "divination", "calendars" etc., are of Sinitic origin, and can be presented as the constituents of Chinese learning. Tangut rituals, Buddhism, and Chinese learning are brought together by the ultimate medium, i.e. the Tangut writing system.

\section{Preliminary Conclusions}

The presentation above is rather fragmentary, and more research is required before one can arrive at well-substantiated conclusions. One preliminary observation is that the invention of script and the development of Tangut philology were never connected with the necessity to translate Confucian texts or introduce Confucian ideology, but to further elaborate the Tangut language and writing system. Buddhism is a more likely candidate for the initial motivation behind the invention of the Tangut script, but even here one should refrain from hasty judgement: we know too little of Buddhism during the initial period of the Tangut Empire. However, one must consider the following: the ideological stance of the texts presented above allows speculating along a different track; in Tangut understanding, the hierarchy of the texts, various departments of science, and learning was based on the idea of the ultimate value of 
their writing system, which is the universal medium for all secondary classifications, such as Buddhism, Confucianism, Daoism, etc.

Another aspect is that Confucianism was never a strong tradition among the Tanguts, whereas Chinese learning, which included military texts, divination, calendar science, etc., was quite influential. This explains why the paradigm of the three teachings (i.e. Confucianism, Buddhism, Daoism) is not applicable to the study of Tangut ideology: one has to admit the domination of Buddhism in every department of the Tangut ideological complex, except for legislation, where the strong presence of Buddhism is nonetheless acknowledged. Chinese learning remained secondary to Buddhism in this respect. What is important here is that all departments of Tangut ideology and culture remained subordinate to the ultimate value of the writing system. The true range of Sinitic (Confucian) influence on the formation of Tangut ideology and culture becomes evident in the universal importance which Tanguts assigned to their writing system, which was synonymous with 'civilization.'

The rise of Confucianism during Renzong's reign probably demonstrated his own sympathies; the constant mention of re-establishing Chinese schools in both Chinese and Tangut sources indicate that Confucianism never had any deep roots in the Tangut Empire. On the other hand, since the time of Qianshun and Renzong, Confucianism started to emerge as the ideology of political legitimation. This feature is historically determined by the specific circumstances of both Qianshun's and Renzong's rise to independent power, but the aspects of Confucianism are of minor importance as compared to the impact it had on the formation of Tangut writing system. Ironically, the most important Sinitic impact, i.e. the creation of the Tangut writing system, which in many ways determined the formation of the Tangut civilization, became not the medium for the Sinicization of the Tanguts but turned out to be the major constituent of their national and ideological identification as the Tangut people.

\section{References}

Dunnell, Ruth. 1995. The Great State of White and High. Honolulu: University of Hawai'i Press. Ecang Heishui Cheng Wenxian 俄藏黑水城文獻. 1997. Vol. 7. Shanghai: Shanghai guji.

Galambos, Imre. 2015. Translating Chinese Tradition and Teaching Tangut Culture: Manuscripts and Printed Books from Khara-Khoto. Vol. 10. Berlin: DeGruyter.

Kychanov, Evegenij Ivanovich. 1968. "Hymn to the Sacred Ancestors of the Tanguts." (Russian). In Written Monuments of the East: Historical and Philological Studies Yearbook 1968, 217-31. Nauka: GRVL.

— 1997. The Sea of Meanings Established by the Saints [More Zanchenij Ustanovlennykh Svaytymi]. St. Petersburg: Petersburskoe Vostokovedenie.

— 2000. "The State and the Buddhist Sangha: Xixia State (982-1227)." Journal of Oriental Philosophy 10: 119-28.

Li Fanwen, 李範文. 1996. "Influence of the Tibetan Buddhism on Xixia" [Zangchuan fojiao dui Xixia de yingxiang 藏傳佛教對西夏的影響]. Lishi Bowuguan guan kan 歷史博物館館刊 3.

, ed. 2007. Xixia Research [Xixia Yanjiu 西夏研究]. Vol. 4. Beijing: Shehui kexue chubanshe.

Li Huarui, 李華瑞. 2010. “Some Problems in the Study of the Tangut Confucianism" [Guanyu Xixia Ruxue yanjiu zhong de jige wenti 關於西夏儒學研究中的幾個問題]. Xixia Xue 西夏 學 6: 109-15. 
Nevskij, Nikolai Aleksandrovich. 1960. Tangut Philology [Tangutskaya Filologia]. Moscow: GRVL.

Nie Hongyin, 聶鴻音. 1999. “A Brief Account of Historical Materials of Xixia Literature” [Xixia wenxue shi liao lueshuo 西夏文學史料說略]. Wenshi 文史 4: 251-62.

—. 2003. “Tangut Translations of the Shijing” [Xixia yi Shi kao 西夏譯《詩》考]. Wenxue Yichan 文學遺產 4: 17-25.

- 2012. "The Tangut Version of the Selections of Taizong" [Xixia ben "Taizong zeyao" chutan 西夏本太宗擇要初探]. Ningxia Shifan xueyuan xuebao 寧夏師範學院學報 2: 55-59.

—. 2016. "Origins of the Tangut Poetry" [Dangxiang shige de xingshi jiqi qiyuan 党項詩 歌的形式及其起源]. Xixia Yanjiu 西夏研究 4: 3-9.

Nishida Tatsuo, 西田龍雄. 1986. Tsuki tsuki gyo shi 月月樂時. Kyoto: University of Kyoto Press.

Peng Xiangqian, 彭向前. 2012. The Study and Editions of the Tangut Translation of the Mengzi [Xixia wen Mengzi zhengli yanjiu 《西夏文《孟子》整理研究》]. Shanghai: Shanghai guji.

Shi Jinbo, 史金波. 1985. Brief History of Tangut Buddhism [Xixia Fojia shilue]. Vol. 10. Yinchuan: Ningxia Renmin.

- 2010. "Problems of Tangut Buddhism and Confucianism" [Guanyu Xixia Fojiao yu ru de jige wenti 關於西夏佛教與儒的幾個問題]. Jiang han luntan 江漢論壇 10: 61-65.

Song Shi 宋史. 1985. Beijing: Zhonghua shuju.

Wen Zhiyong, 文志勇, and Cui Hongfen 崔紅芬. 2006. “The Development of the Tangut Confucianism and the Relationship Between Tangut Buddhism and Confucianism" [Xixia ruxue de fazhan he rushi guanxi chutan 西夏儒學的發展和儒釋關係初探]. Xibei minzu yanjiu 西北民族研究 1: 33-42. 